\title{
Physiological Quality of Bean Seeds Related To Azotobacter spp. Inoculation
}

Qualidade fisiológica de sementes de feijão associada à inoculação de Azotobacter spp.

\author{
Luna Valentina Angulo Arias ${ }^{1}$, Paulo Ademar Martins Leal ${ }^{2}$, Rosa Helena \\ Aguiar $^{3}$, Thais Queiroz Zorzeto ${ }^{4}$ \\ 1,2,3,4 (College of Agricultural Engineering/University of Campinas, Brasil)
}

\begin{abstract}
Research aimed at improving the quality of crops. The results obtained with seed coating were very influential with regard to fertilization and disease resistance. Nitrogen fertilization increases costs in agricultural production and the loss of fertile lands, altering the natural conditions and has negative consequences for the microorganisms (MO), which regulate the balance between quality of crops and soils. The biological nitrogen fixation (BNF) consists on $M O$ work which provide nitrogen in soil and secrete substances that promote plant growth, these can be made by inoculation of seeds. The germination rate, emergency and vigor are an indicator that determines the productivity and physiological quality of a plant variety. The germination rate, number of emerged seeds per pot in favorable field conditions and vigor by accelerated aging test were evaluated. The seed treatments were: the seed inoculation with Azotobacter spp., Immersion in nutrient broth without bacteria, sterilization and zero handling. The experiment has shown that inoculation of common bean seeds with Azotobacter spp. does not adversely affect germination, emergency or vigor and stimulate the development of abnormal seedlings.
\end{abstract}

Index terms: agriculture, covering, green house, vigor.

Resumo:As pesquisas visam melhorar a qualidade das culturas. Os resultados obtidos com recobrimento de sementes foram muito influentes com relação à adubação e resistência às doenças. A adubação nitrogenadaaumenta os custos na produção agrícola e a perda de solos férteis,altera as condições naturais e traz consequências negativas para os micro-organismos (MO), que regulam o equilíbrio entre culturas e solos. A fixação biológica do nitrogênio ( $F B N$ ) é fruto do trabalho de MOque disponibilizam o nitrogênio no solo e segregam substâncias que promovem o desenvolvimento vegetal; esses MOpodem ser adicionados por meio da inoculação das sementes. Oíndicede germinação, emergência e vigor permitem determinar a produtividade e a qualidade fisiológica de uma cultivar. Avaliaram-se o indice de germinação, número de sementes emergidas por vaso em condições favoráveis de campo e o vigor (envelhecimento acelerado). Os tratamentos das sementes foram: a inoculação das sementes com Azotobacter spp., a imersão em caldo nutritivo sem bactéria, a esterilização e sem manipulação. O experimento permitiu verificar que a inoculação das sementes de feijão carioca com Azotobacter spp.nãoafeta negativamente a germinação, a emergência e nem o vigor, pois estimula o desenvolvimento de plântulas anormais.

Termos para indexação:agricultura; cobertura; estufa; vigor.

\section{Introduction}

At the last years, the interest of non-pollutant and safe production of food has been increased. An excessive use of nitrogen and chemical fertilizers increase the cost of the production system and decreases soil fertility. The soil acidification is just one of the examples that affect the equilibrium between the soil microorganism and soil which are responsible for the soil fertility and productive crops. To decrease chemical fertilizers use in legumes production has been possible because of the seed or soil inoculation with nitrifying microorganisms (Azotobacter spp.). The biological fixation of nitrogen is a natural process where the nitrogen is simplified to the plants nutrition. Focusing of the need of keep the equilibrium, researches look for the development of treatments able to increase the production at low cost without affect physiological qualities of seeds or the environment. These researches mean to improve seeds able to develop resistant diseases plants and normal development in a deficient nutrient soil.

Related to LOBO et al. (2013), quality seeds are those which have high germination and vigor, high genetic and physical pure, these characteristics are determinate by the use of tests of germination rate or accelerated aging test. Seeds of quality are able to develop a uniform crop, increase de enhance of supplies, avoid the propagation of diseases and decrease the dissemination of harmful plants residents of the soil (SILVA, 2003). The quality of the seeds can be affected by inoculation treatments or others that have the objective of improve the resistant for any disease, improve the efficiency of nutrient absorption and others improvement 
mechanism. The inoculation with biological or chemical agents are the treatments more using in searching, being the inoculation with nitrifying microorganism one of the most reference in the last years, it is because those microorganism made the nitrogen able to the plants nutrition.

According to DENARDIN (2010), the success of the biological fixation of nitrogen technology is related to the appropriate establishment of a symbiosis between the microorganism and the plant, besides high inoculant products and safe relationship with the seed. The maximizing of nitrogen supply to the crop like soy and bean depends on the inoculant quality and the management of the efficient interaction between plan and microorganism.

In addition, TORRES et al. (2002) state that the used of biological fertilizers is favorable to the costs and eliminates harmful effects of nitrogen fertilizers in the absorption, the assimilation and availability of nutrients like phosphorus. Besides, helps to the elimination of air pollution, groundwater and phreatic mantle.Summarizing reduces the environment and economic impact.

Beans are one of the most consumed dishes in Brazil, it is part of the basic diet and it is important to keep it able at the market. To produce it, they are necessary a lot nitrogen fertilizers that are expensive, but, with the inoculation of seeds with nitrifying microorganism it is possible to decrease nitrogen fertilization and the environment damage. But it is possible that the inoculation affect the seeds quality, being necessary to evaluate the response of those seeds at the initial steps of the vegetal development. To conclude, the objective of this work was to verify if the inoculation with Azotobacter spp.in bean, affect the physiological quality of the seeds and the experiment has shown that inoculation of common bean seeds with Azotobacter spp. does not adversely affect germination, emergency or vigor and stimulate the development of abnormal seedlings.

\section{Seeds}

\section{Material And Methods}

Carioca bean seeds were used, potential productivity of $4.351 \mathrm{~kg} \cdot \mathrm{ha}^{-1}$, semi erect, high quality of grains, mass of 300 grams per 1000 seeds, moderate resistance to anthracnose, physical purity of $99.9 \%$ and germination rate between $60 \%$ and $74 \%$.

\section{Inoculation product}

To the seeds inoculation it was prepared a product with an Azotobacter chroococcum concentration higher than $1 \times 10^{9}$ viable cells per mL. The Azotobacter spp. was isolated from a red latosol soil sample of the experimental area with the chemical characteristics showed on Table 1.

Table 1. Result of the soil chemical analysis of the experimental area.

\begin{tabular}{|c|c|c|c|c|c|c|c|}
\hline $\mathbf{N}$ & $\mathbf{P}$ & $\mathbf{K}$ & $\mathbf{C a}$ & Mg & $\mathbf{S}$ & $\mathbf{H}+\mathbf{A l}$ & C.T.C. \\
\hline $\mathrm{g} \mathrm{kg}^{-1}$ & $\mathrm{mg} \mathrm{dm}^{-3}$ & mmolc dm ${ }^{-3}$ & mmolc dm ${ }^{-3}$ & mmolc $\mathrm{dm}^{-3}$ & $\mathrm{mg} \mathrm{dm}^{-3}$ & mmolc $\mathrm{dm}^{-3}$ & mmolc dm ${ }^{-3}$ \\
\hline 1 & 15 & 3,1 & 27 & 8 & - & 27 & 65,1 \\
\hline M.O. & pH & $\mathbf{V}$ & B & $\mathrm{Cu}$ & $\mathbf{F e}$ & Mn & $\mathbf{Z n}$ \\
\hline $\mathrm{g} \mathrm{dm}^{-3}$ & - & $\%$ & $\mathrm{mg} \mathrm{dm}^{-3}$ & $\mathrm{mg} \mathrm{dm}^{-3}$ & $\mathrm{mg} \mathrm{dm}^{-3}$ & $\mathrm{mg} \mathrm{dm}^{-3}$ & $\mathrm{mg} \mathrm{dm}^{-3}$ \\
\hline 25 & 5 & 59 & 0,28 & 10,4 & 27 & 14,4 & 1,2 \\
\hline
\end{tabular}

M.O: Organic matter; C.T.C: Cation exchange capacity; V\%: Base Saturation.

Then it was prepared $1 \mathrm{~L}$ of nutrient broth(Table2), being autoclaved to eliminate microorganisms that could inhibit Azotobacter chroococcum growth. The nutrient broth was inoculated with Azotobacter chroococcum following the BENSON (2001) method to transference of bacteria from a solid medium to a liquid one. It consist in select the best colonies of the broth pure colony that want to propagate and inoculate de nutrient broth.

Table 2. Nutrient broth formulation

\begin{tabular}{lcc}
\hline \multicolumn{1}{c}{ Reactive/product } & Quantity/Littre & Observations \\
\hline Mannitol & $20 \mathrm{~g}$ & $\mathrm{pH}$ at $25^{\circ} \mathrm{C}$ \\
$7,4 \pm 0,2$ & \\
\hline Dipotassium Phosphate & $0,2 \mathrm{~g}$ & \\
\hline Magnesium Sulphate & $0,2 \mathrm{~g}$ & \\
\hline Sodium Chloride & $0,2 \mathrm{~g}$ & \\
\cline { 1 - 2 } Potassium Sulphate & $0,1 \mathrm{~g}$ & \\
\hline Calcium Carbonate & $5 \mathrm{~g}$ & \\
\hline Distilled water & $1 \mathrm{~L}$ & \\
\hline
\end{tabular}

\section{Treatments}

To the seeds inoculation were used $200 \mathrm{~g}$ of seeds per treatment randomly selected from the package.The 4 treatments applied to the seeds were: (T1) inoculation with the inoculation product, (T2) inoculation with the nutrient broth, (T3) sterilization and (T4) not treatment. To the treatment 1 (T1), 
sterilization was performed with ethanol at $1 \%$ andcommercial chlorine at $10 \%$ in immersion for 3 minutes, quick wash with sterile water, related to PINEDA et al. (2005) method. Then, the seeds were inoculated by immersion in the inoculation product with continuous agitation of $150 \mathrm{rpm}$ for 15 minutes.

At the treatment 2 (T2), sterilization was performed with ethanol at $1 \%$ and commercial chlorine at $10 \%$ in immersion for 3 minutes, quick wash with sterile water, related to PINEDA et al. (2005) method. Then, the seeds were inoculated by immersion in the nutrient broth with continuous agitation of $150 \mathrm{rpm}$ for 15 minutes.To the treatment 3 (T3), sterilization was performed with ethanol at $1 \%$ and commercial chlorine at $10 \%$ in immersion for 3 minutes, quick wash with sterile water, related to PINEDA et al. (2005) method.

At the treatment 4 (T4), the seeds were not subjected to any manipulation.

\section{Germination test}

To the germination test it was considered the established method of the Rules for Seed Analysis(RAS) related to BRASIL (2009), it was used wet paper tower as substrate and keeping a controlled temperature of $25^{\circ} \mathrm{C}$. The initial counting occurred on the fifth day after the initiation of the test and the final counting was on the ninth day, considering the criteria for normal and abnormal seedlings and a minimum of $2 \mathrm{~cm}$ length.

The statistical treatment of data was a completely randomized design with four repetitions per treatment and fifty seeds for each repetition. The data were submitted to analysis of variance by $\mathrm{F}$ test and the difference between the averages compared by Tukey test at $\mathrm{p}<0,05$ significance level.

\section{Emergency test}

To the emergency test it was made an installation of pots with soil in greenhouse. The soil used was the same collected to the microorganism isolation. It was designed 100 pots per treatment, where each pot contained 3 sowed seeds. The emergency was evaluated by the quantity of emerged seeds per pot. The first counting was on the fifth day after sowing and every day until the tenth. Were considered like emerged those seedlings whose cotyledon appeared on the soil surface.The statistical treatment of data was a randomized block design with four treatments, four blocks, and twenty five repetitions. The data were submitted to analysis of variance by $\mathrm{F}$ test and the difference between the averages compared by Tukey test at $p<0,05$ significance level.

The greenhouse, oriented north-south position, has the following characteristics: 6,4x11 x3,0 in meters, with $4,5 \mathrm{~m}$ of total height to ridge; gabled roof covered with low density polyethylene (PEBD) with $150 \mu \mathrm{m}$ of thickness, treated against ultraviolet rays, light diffusor, antivirus. The greenhouse was able to keep temperatures between $28^{\circ} \mathrm{C}$ and $30^{\circ} \mathrm{C}$ with a relative humidity between 65 and $70 \%$, mechanical ventilation, evaporative cooling and mobile term-reflective screen, with anti-aphid screenat the openings.

\section{Vigor test}

Related to the accelerated aging test method, the seeds were submitted to a temperature of $42^{\circ} \mathrm{C} \pm 2{ }^{\circ} \mathrm{C}$ for $72 \mathrm{~h}$ (VIEIRA\&CARVALHO, 1994), the it was evaluated the germination rate considering the established method of the Rules for Seed Analysis (RAS) related to BRASIL (2009), it was used wet paper tower as substrate and keeping a controlled temperature of $25^{\circ} \mathrm{C}$. The initial counting occurred on the fifth day after the initiation of the test and the final counting was on the ninth day according to the RAS for bean seeds.

The statistical treatment of data was a completely randomized design with four repetitions per treatment and fifty seeds for each repetition. The data were submitted to analysis of variance by $\mathrm{F}$ test and the difference between the averages compared by Duncan test at $\mathrm{p}<0,05$ significance level.

\section{Results And Discussion}

The results of the germination test (Table 3 ), showed that it was a statistical significant effect $(p<0,01)$. The seeds submitted to the treatment with the inoculation product (T1) had the higher germination rate (93\%) and less abnormal seedlings (6\%), related to the others treatments, improving the seed`s physiological quality.

Table 3. Number of germinated seeds and germination rate of normal and abnormal seedlings to each treatment: $\mathrm{T} 1$ (inoculation with the inoculation product), T2 (inoculation with the nutrient broth), T3 (sterilization) and T4 (not treatment)

\begin{tabular}{ccccccc}
\hline \multirow{2}{*}{ Treatment } & \multicolumn{3}{c}{ Number of germinated seeds } & \multicolumn{2}{c}{ Germination rate (\%) } \\
\cline { 2 - 7 } & Normal & $* *$ & Abnormal & Normal & Abnormal \\
\hline T1 & 47 & a & 3 & c & 93 & 6 \\
\hline T2 & 44 & a & 6 & c & 88 & 11 \\
\hline T3 & 35 & b & 16 & b & 69 & 31 \\
\hline T4 & 25 & c & 25 & a & 50 & 49 \\
\hline
\end{tabular}

Means followed by the same letter are not statistically different from each other. Applied Tukey test $(\mathrm{p}<0,05)$. 
In the emergency results under favorable conditions of greenhouse all the four treatments showed a similar behavior of a rising emergency along the days (Figure 1). However, it is found that seed inoculation with Azotobacter chroococcum had no negative effect on germination rateand emergency of bean seeds. In contrast, in a research directed by BASSAN et al. (2001) there was not effect of the inoculation with the diazotrophic microorganism related to the germination rate and the emergency. The germination power (defined by the percentage of germinated seeds) allows to check the capacity and the potential of the seeds to generate a new perfect and vigorous plant under favorable conditions (VIEIRA \& RAVA, 2000), according with them, the seeds of T1 are able to generate new healthy and vigorous plants under favorable condition in a higher percent related with the others treatments.

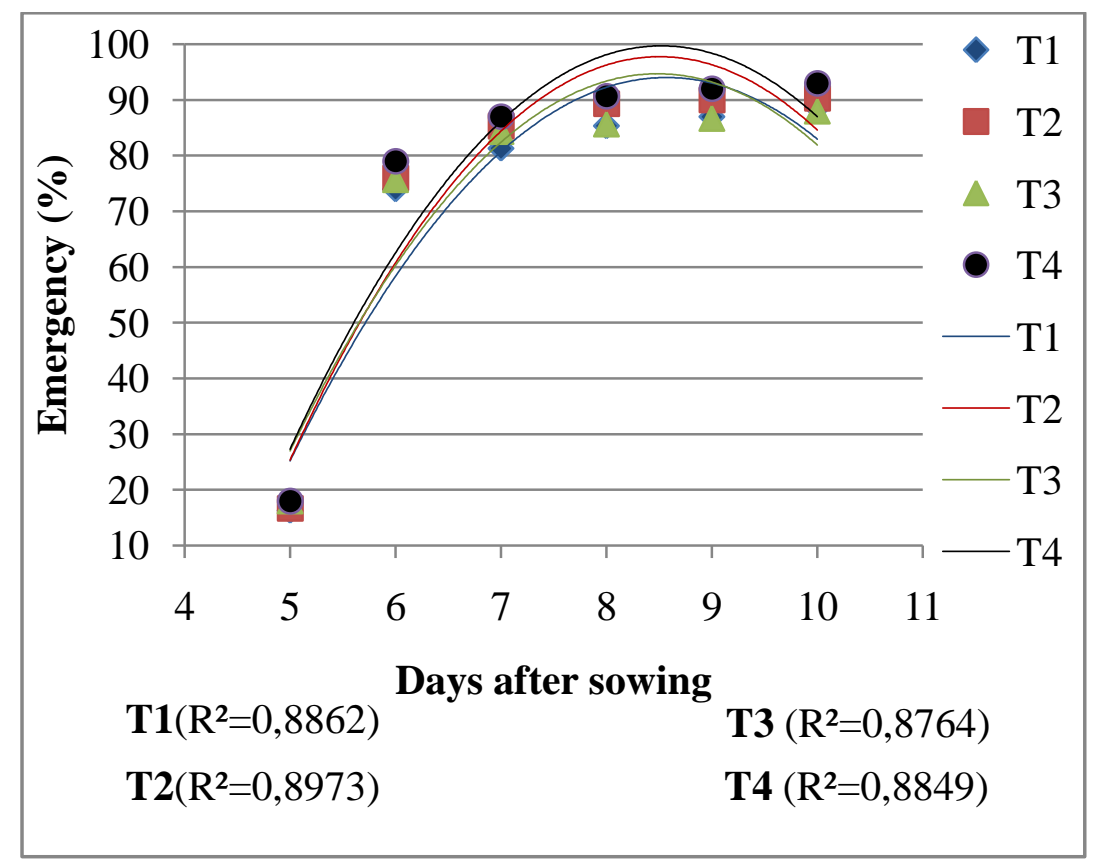

Figure 1. Behavior of the seed`s emergency under favorable conditions of greenhouse, submitted to the treatments: T1 (inoculation with the inoculation product), T2 (inoculation with the nutrient broth), T3

(sterilization) and T4 (not treatment).

The seeds that were not subjected to any manipulation (T4) should have shown a germination rate between $60 \%$ and $74 \%$ but that rate was less than $50 \%$. It could be because of an external factor that affected the seeds.

OGATA et al. (2008) research about the effect of different kind of microorganism in the germination of some cultivars including beans where Azotobacter spp. was one of the inoculation microorganisms. The authors checked that most of the strains increase the percentage of the cultivars germination when compared with a not inoculated cultivar. InCanario camanejo bean, the inoculation showed higher rates of germination with percentages above $90 \%$ and for Caraota bean, $22 \%$ of the inoculated treatments showed a significant increase of the germination rate (137\%).However, $78 \%$ showed a similar behavior than the not inoculation treatment. OGATAet al. (2008) suggest that strains of Azotobacter spp. could be used in a monoculture system.

Despite the differences between the germination rates, the emergence results under favorable conditions the greenhouse showed a similar response to all treatments (Figure 1) without significant effect of the treatment so, the treatment do not affect the emergency of the seeds. According to HUNGRIA et al. (1997), the non-symbiotic inoculation is more susceptible to the environment conditions, decreasing the efficiency of the microorganisms biologic nitrogen fixation and consequently, like showed in this research, the inoculation did not affect the emergency. The Figure 1shows that the rate emergency was higher than $74 \%$ after 6 days of sowing for all treatments.All treatment seeds are able to generate a normal plant under favorable conditions of greenhouse.

The equations for the treatments $1,2,3$ e 4 were $y=-302,86+92,633 x-5,4048 x^{2} ; y=-328,14+$ $100,14 x-5,8869 x^{2} ; y=-306,76+94,642 x-5,5774 x^{2} ;$ e $y=-324+99,433 x-5,8333 x^{2}$; respectively. The $R^{2}$ are in the Figure 1. The curves showed a simulated behavior that reflects a maximum of emergency point, this allows us to infer the percentage of seedlings that could be able to generate a normal plant in the controlled conditions of a greenhouse and how long it will take to the cultivar get at the maximum percentage of 
germination. It is important information that can be used like a tool to help in the fertilization plan and in the prediction of the productivity.

The result of the vigor test, where the seeds were submitted to high temperature and humidity and then tested by the germination test; showed lower percentage of germinate rate than those seeds that were not submitted to the temperature and humidity stress. According to BINOTTI et al. (2008) whena seed is submitted to an adverse environment under a longer time, then, the deterioration rate will be higher.

The Table 4shows the results after vigor test, where the seeds with the inoculation product (T1) had the higher germination rate $(73 \%)$, this result is between the accepted rate for the cultivar (60-74\%). This group of seed had also the lower percentage of abnormal seedlings (16\%) when compared to the $32 \%$ of the group of seeds that were not manipulated (T4). The group of seeds that were not manipulated (T4) must have had a germination rate of $60 \%$ under normal conditions, this rate was not reached after the vigor test and after the germination test the result was lower (50\%). Therefore, according to the information, there were external factors that affect the seeds before the treatments.

Table 4. Vigor test.Number of germinated seeds and germination rate of normal and abnormal seedlings to each treatment: T1 (inoculation with the inoculation product), T2 (inoculation with the nutrient broth), T3

(sterilization) and T4 (not treatment)

\begin{tabular}{ccccccc}
\hline Treatment & \multicolumn{2}{c}{ Number of germinated seeds } & \multicolumn{2}{c}{ Vigor test (\%) } \\
\cline { 2 - 7 } & Normal & $*$ & Abnormal & $* *$ & Normal & Abnormal \\
\hline T1 & 36 & a & 8 & b & 73 & 16 \\
\hline T2 & 34 & ab & 8 & b & 69 & 15 \\
\hline T3 & 30 & b & 14 & a & 60 & 29 \\
\hline T4 & 29 & b & 16 & a & 57 & 32 \\
\hline
\end{tabular}

Means followed by the same letter are not statistically different from each other. Applied Duncan test $(p<0,05)$ e

$$
(0,01=<\mathrm{p}<0,05) \text {. }
$$

State that there were significant treatments effects (Table 4), and there was not statistical difference between T2, T3 e T4.InCRUSCIOL et al.(2003) research, were applied doses of nitrogen $(\mathrm{N})$ to the sowing with not consist results about the effect of the application related to the seed`s physiological quality. The authors state that there was not a positive effect of the nitrogen fertilization related to the germination and the vigor of the seeds. But,there was a positive effect of the inoculation with Azotobacter spp.related to physiological quality of bean seeds. However, this positive effect is attributed to the Azotobacter's ability to secrete hormones that promote the plant development in the early stage and not to its ability to fix nitrogen. Those CRUSCIOL et al.(2003) results explains why in this research there was a significant effect of the treatments in the germination and vigor of bean seeds but not significant effect to the emergency.

\section{Conclusions}

The inoculation with Azotobacter spp. of bean seeds has apositive effect related to the germination and the vigor, stimulating the development of abnormal seedlings outperforming the average rates. The inoculation with Azotobacter spp.improves the physiological quality of bean seeds, allowing an appropriate initial crop development. The exploitation of the biological nitrogen fixation ofAzotobacter spp.does not affect the physiological quality of bean seeds.

\section{References}

[1]. BENSON: Microbiological Applications: Laboratory Manual in general Microbiology, Eighth Edition. The McGraw-Hill, 2001. $478 \mathrm{p}$.

[2]. Brasil. Ministério da Agricultura, Pecuária e Abastecimento. Regras para análise de sementes / Ministério da Agricultura, Pecuária e Abastecimento. Secretaria de DefesaAgropecuária. - Brasília: Mapa/ACS, 2009. 399 p.

[3]. CRUSCIOL, C. A. C.; LIMA, E. D.; ANDREOTTI, M.; NAKAGAWA, J.; LEMOS, L. B.; MARUBAYASHI, O. M. Efeito do nitrogênio sobre a qualidade fisiológica, produtividade e características de sementes de feijão.Revista Brasileira de Sementes, 25(1): 108-115, 2003.

[4]. SILVA, C. C. Sistemas de Produção, 2. Cultivo do feijoeiro comum: Plantio. Embrapa Arroz e Feijão, 2003. Versão eletrônica. Available at: < https://sistemasdeproducao.cnptia.embrapa.br/FontesHTML/Feijao/CultivodoFeijoeiro/plantio.htm>. Accessed on: January, 11, 2016.

[5]. DENARDIN, N. fixação biológica de nitrogênio em interação com produtos fitossanitários, químicos e biológicos, por leguminosas. Avanços no tratamento e recobrimento de sementes. Informativo. ABRATES, Brasil; 20(3): 62-69, 2010.

[6]. HUNGRIA, M.; ANDRADE, D. S.; BALOTA, E. L.; COLOZZI-FILHO A. Importancia do sistema de semeadura direta na população microbiana do solo.EMBRAPA. Centro Nacional de Pesquisa de Soja. Comunicado tecnico, (53): 1-9. 1997.

[7]. LOBO, M. J.; BRANDÃO, L. T. D.; MARTINS, B. E. M. Testes para Avaliação da Qualidade de Sementes de Feijão Comum Bárbara Estevam de Melo. Santo Antônio de Goiás: Embrapa Arroz e Feijão. Embrapa Arroz e Feijão. Circular técnica (90): 4p. 2013.

[8]. OGATA, K.; ARELlANO, C.; ZUÑIGA, D.. Efecto de diferentes bacteriasaisladas de rizósfera de Caesalpinaspinosaenlagerminación de diferentes especiesvegetalesculivados. Zonas Aridas, Peru; 12 (1): 13-35. 2008.

[9]. PINEDA, J.; HERNANDEZ, A.; GONZALEZ, A.; BARRIENTOS, V.; NASS, H.; GIL, E. Tecnica de inoculacion rápida y eficiente para la evaluación de materiales de maiz ante Rhizoctonia solani Kühn. Bioagro, Venezuela; 17 (2): 93-98. 2005.

[10]. TORRES, R.; SORIA, E.; PEREZ, C.; GARCIA. J. Incrementos En La Fijación Biológica De N2 Atmosférico En El Cultivo Del Frijol (PhaseolusVulgaris L.) Mediante La Inoculación Combinada De Bacterias Diazotróficas. Centro de Desarrollo Agrícola de las FAR, AGROFAR. Cuba, Santo Domingo, Villa Clara. 2002.

[11]. VIEIRA, E. H. N.; RAVA, C. A. (Ed.). Sementes de feijão: produção e tecnologia. Santo Antônio de Goiás: Embrapa Arroz e Feijão, 270 p. 2000.

[12]. VIEIRA, R. D.; CARVALHO, N. M. Testes de vigor em sementes. Jaboticabal: FUNEP. Brasil, 164 p. 1994. 